\title{
Source correlation of biomarkers in a mangrove ecosystem on Santa Catarina Island in southern Brazil
}

\author{
CESAR A. SILVA and LUIZ A.S. MADUREIRA \\ Laboratório de Química Ambiental e Geoquímica Orgânica, Departamento de Química, \\ Universidade Federal de Santa Catarina (UFSC), 88040-900 Florianópolis, SC, Brasil \\ Manuscript received on July 28, 2010; accepted for publication on September 28, 2011
}

\begin{abstract}
The relative distribution of several compounds identified in four samples of recently deposited sediments of the Itacorubi Mangrove located on the Santa Catarina Island, southern Brazil, was compared with similar data on compounds extracted from fresh leaves of three mangrove species (Avicennia schaueriana, the dominant species in the area, Rhizophora mangle and Laguncularia racemosa) and the Gramineae Spartinna alterniflora. Terpenols, previously identified in mangrove species in northern Brazil, were also found. $A$. schaueriana mainly contains $\beta$-amyrin $\left(90.6 \mu \mathrm{g} \mathrm{g}^{-1}\right.$ of extractable organic matter); low amounts of friedelin, betulin and germanicol were detected only in the leaf extract of this species. $R$. mangle also contained a significant amount of $\beta$-amyrin and it was the only species where taraxerol was detected. In contrast to the leaves, sediment extracts were dominated by germanicol, $\alpha$-amyrin and campesterol. Despite its chemical lability, betulin was also detected. Two homologous series of $\alpha$ and $\omega$-hydroxy fatty acids were detected in the acid-alkaline fraction. In spite of being reported in the literature as components of terrigenous plants, saturated $\omega$-hydroxy acids were not identified. Our results indicate that although triterpenols may be used as biomarkers for mangrove-derived organic matter, their relative distribution can change according to the region.
\end{abstract}

Key words: biomarkers, leaf, mangrove, Santa Catarina, sediment.

\section{INTRODUCTION}

Mangrove ecosystems are characterized by high primary productivity, high levels of organic carbon, abundant detritus and anoxic/reduced conditions. The forests are best developed under tropical climates, where the coldest winter temperature is above $20^{\circ} \mathrm{C}$ and temperatures are fairly constant throughout the year. Mangroves are salttolerant trees and grow mainly along low-lying

Correspondence to: Luiz Augusto dos Santos Madureira E-mails: lasmadureira@bol.com.br /

luiz.madureira@ufsc.br depositional coasts and deltas, where the substrate is predominantly made of clay and silt rather than sand. Since nutrients are often adsorbed onto sediment particles, inputs of mangrove-derived organic matter into tidal creeks and estuaries are important for coastal zooplankton and fish populations (Lacerda 1998, Koch et al. 2003). Previous studies have emphasized the importance of leaf litter as the major component of the total litterfall of mangrove forests as a carbon source and thus in the identification of specific biomarkers (Koch et al. 2003, 2011). Hence, mangroves represent favorable environments where 
an important uptake, conservation and accumulation of biomarkers such as hydrocarbons, triterpenols, sterols and fatty acids may occur (Mater et al. 2004, Koch et al. 2005, Farias et al. 2008).

The presence of biomarkers in sediments has been widely used as a proxy to evaluate possible sources of organic matter (Rieley et al. 1991). Organic compounds such as terpenols, $n$-alkanols, $n$-alkanes, fatty acids and hydroxy acids (Keinänen et al. 2003) and lignin phenols (Pempkowiak et al. 2006, Rezende et al. 2010) are particularly important to estuaries. However, it is well known that it is difficult to find correlations between organic compounds and a specific living organism, and other biogenic parameters (e.g. C, N, and P) and the isotope composition of individual compounds (Vogts et al. 2009) may be used for the assessment of specific sources (Madureira et al. 1997, Xu et al. 2001, RuizFernandéz et al. 2002, Bouillon et al. 2003). In the particular case of mangroves, the vegetation is well characterized and compounds like taraxerol and germanicol have been used as a lipid biomarker for mangrove-derived organic matter (Koch et al. 2005, 2011). Estuarine sediments are of great complexity due to the tidal influx of allochthonous organic matter and also the input of terrigenous debris from the local vegetation (Bouillon et al. 2003). Thus, it is important to employ as many parameters as possible to evaluate the dominant indicators for terrestrial and aquatic inputs. Apart from natural contributions, mangroves are also susceptible to inputs of pollutants from diffuse sources. In most coastal areas, mangroves are important receptors of pollutants from the atmosphere, continental runoff and tidal currents.

In recent years, the pressures of increasing population, food production, and industrial and urban development have caused a significant proportion of the world's mangrove resources to be destroyed. There are five well-defined mangrove areas at Santa Catarina Island, but they are under the constant threat of losing their protection due to changes in municipal and federal laws. Several studies have already empha- sized the great importance of the mangroves located at Santa Catarina Island as natural habitats and food sources for many crustaceans, fishes and reptiles (Dutra 1998, Soriano-Sierra and Ledo 1998). In this regard, our contribution was to analyze biogenic parameters, as well as organic compounds, extracted from the four predominant plant species and sediment samples taken from the Itacorubi Mangrove ecosystem. The aim was to obtain information on the relative contribution of the leaves of mangroves species, bacteria and microalgae to the mangrove sediments. Sterols, triterpenols, $n$-alkanes, hydroxy and $n$-alkanoic acids are the principal compound classes that will be addressed in this study. Moreover, following the procedure described by Garcette-Lepecq et al. (2004), all of the leaf and sediments samples were submitted to sequential treatment with base and acid hydrolysis after being solvent-extracted. According to the authors, the bound acid fractions reflect differences in the linkage mode of the acid moieties and/or in the protection provided by the (macro) molecular structures into which they are incorporated.

Sterols are widely distributed in living organisms. Potential sources include sewage matter, estuarine phytoplankton and zooplankton and terrestrial vascular plants. Some types of sterols may also originate from a synthesis within the sediments and from secondary transformation products arising from the bioconversion of primary sterols (Volkman 1986). $\mathrm{C}_{28}$ and $\mathrm{C}_{29}$ desmethyl sterols in sediments that are believed to originate predominantly from vascular plants include: campesterol (24-methyl-5-cholesten-3 $\beta$ ol), $\beta$-sitosterol ( $24 \alpha$-ethyl-5-cholesten-3 $\beta$-ol) and stigmasterol (24 $\alpha$-ethyl-5, (22E)-cholestadien3ß-ol) (Heftmann 1971). The distribution of triterpenols in the leaves of mangrove species may vary significantly. Large amounts of betulin, lupeol, $\beta$-amyrin and taraxerol have been reported in the literature (Koch et al. 2003).

The within-class distributions of long-chain $\left(>\mathrm{C}_{20}\right) n$-alkanes, $n$-alkanoic acids and $n$-alkanols 
are often used to infer terrestrial inputs to sediments. These compounds are abundant in plant epicuticular waxes, but long-chain $n$-alkanes and $n$-alkanoic acids can also be found in marine algae (Volkman et al. 1980, Venkatesan and Kaplan 1982). As previously reported, in $R$. mangle leaves odd $n$-alkanes $\left(\mathrm{C}_{25}, \mathrm{C}_{27}\right.$ and $\mathrm{C}_{29}$ ) are predominant (Hernandez et al. 2001).

With regard to unsaturated fatty acids, these mainly occur in bacteria and microalgae. However, their structure, especially the double bond location, can help to discriminate among such sources (Garcette-Lepecq et al. 2004). For hydroxy acids several sources can be considered. They can be originated during the diagenesis through microbial oxidation of fatty acids. Medium and longchain $\alpha$-hydroxy acids, as well as medium-chain $\beta$-hydroxy acids, are also produced by microalgae and seagrasses (de Leeuw and Largeau 1993, de Leeuw et al. 1995, Versteegh et al. 1997).

\section{EXPERIMENTAL}

\section{STUDY AREA}

The Itacorubi Mangrove ecosystem is located at the southern limit of the mangrove distribution area of the Brazilian coast (coordinates: $27^{\circ} 34^{\prime} 14^{\prime \prime}-27^{\circ} 35^{\prime}$ $31^{\prime \prime} \mathrm{S}$; $48^{\circ} 30^{\prime} 07^{\prime \prime}-48^{\circ} 31^{\prime} 33^{\prime \prime} \mathrm{W}$ ) and occupies a surface area of $1.42 \mathrm{~km}^{2}$ in an estuarine basin of $22.12 \mathrm{~km}^{2}$ (Figure 1). Two rivers, the Itacorubi and the Sertão, 5.9 and $4.0 \mathrm{~km}$ long respectively, as well as natural and artificial channels, cross a welldeveloped forest (Dutra 1998).

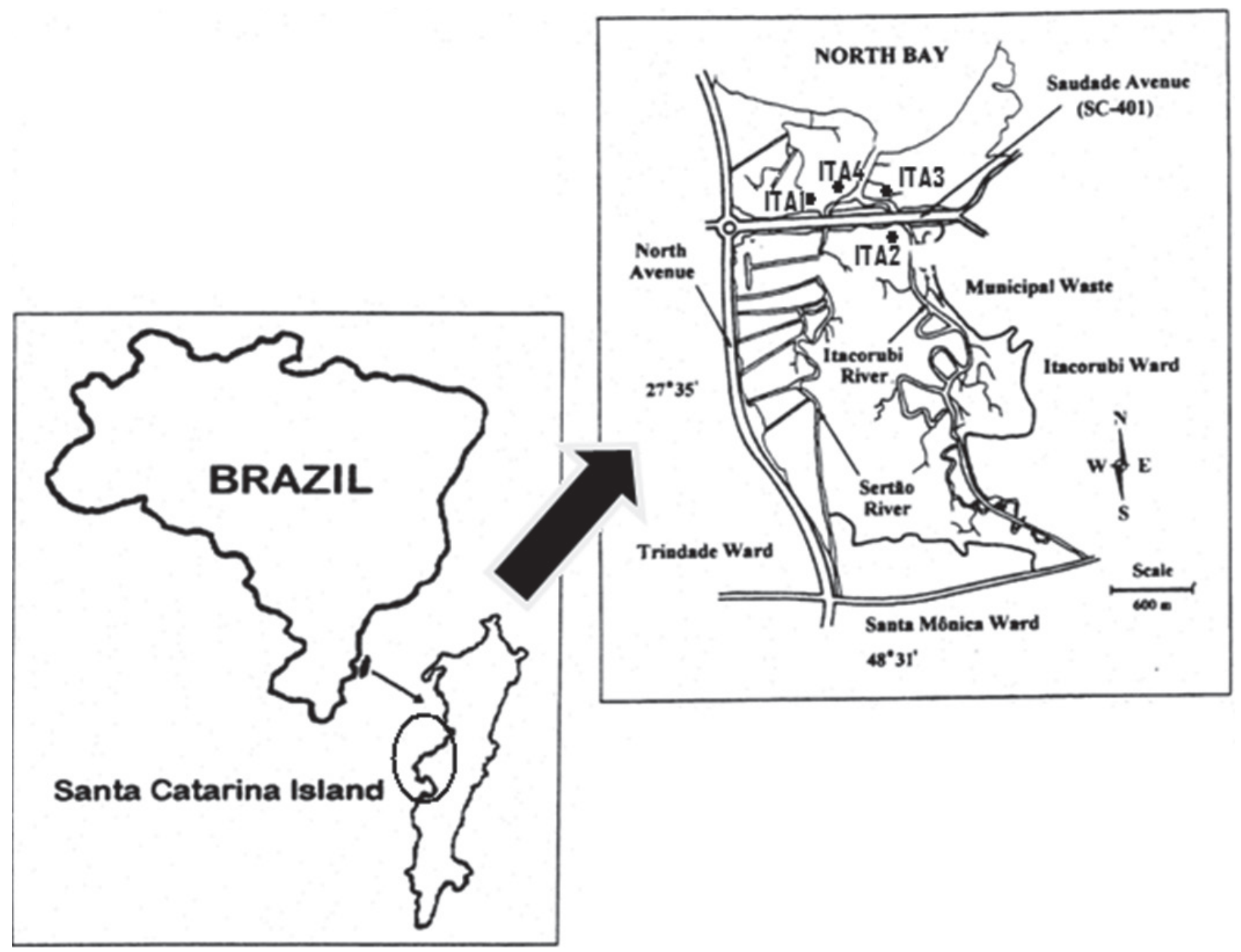

Figure 1 - Map showing the location of Itacorubi Mangrove at Santa Catarina Island and the sampling locations. 
Three mangrove species are present in the forest: Rhizophora mangle, Laguncularia racemosa and Avicennia schaueriana, in dense populations - approximately 2900 per ha. $A$. schaueriana, the dominant species (90\%), has some individual trees over five meters high, with a density of 800 adult trees per ha (Soriano-Sierra and Ledo 1998). Spartina alterniflora is a species of grass that grows in tallest forms at the outermost edge of the marsh, creating mud banks like islands with approximately $133 \mathrm{~m}$ of radius.

This ecosystem has been progressively eliminated during the past 40 years, although it is mentioned in the current national legislation as an "Area of Permanent Preservation". Environmental changes have taken place in this mangrove system due to the impact of anthropogenic processes (Lago 1997). The mangrove served as an area for the disposal of solid waste material until 1980, receiving a total volume of 75,000 tons of domestic garbage, industrial and hospital waste, all of which were deposited in layers superposed on a sanitary landfill occupying a surface area of $12 \mathrm{ha}$. Artificial channels, $6.1 \mathrm{~km}$ long in total, have been built to discharge rainwater and domestic effluents to the coastal zone (Soriano-Sierra and Ledo 1998). The Itacorubi Mangrove has been used for subsistence fishing by a reduced number of fishermen but, due to its location, it is becoming an object of urban management, resulting in the elimination of some sectors to obtain land for the construction of residences and roads.

SAMPLING

Fresh leaves from $R$. mangle, L. racemosa, $A$. schaueriana and $S$. alterniflora were collected along transects from the sea side to the land side of the mangrove. In order to avoid possible variations in the lipid composition among the trees and leaves of different developmental stages, only fully mature foliage from adult individuals was collected. Also, trees with the presence of epiphytic colonization were avoided due to the potential contamination of leaves. All leaves were transferred to and stored in previously-combusted $\left(450{ }^{\circ} \mathrm{C}\right)$ glass jars sealed with aluminum foil-lined lids and kept frozen until freeze-drying in the laboratory. Sediment samples were collected from near the surface (0-5 cm depth) with a van Veen grab sampler at the same intertidal zone from which the leaves were collected. The sediment samples named ITA1 and ITA4 were taken from subtidal areas, whereas ITA2 and ITA3 were sampled from intertidal areas.

BulK PARAMETERs AND PARTICle Size Distribution

Immediately prior to lipid extraction, the storage solvent was evaporated and the sediment freezedried (Edwards F105) under vacuum and homogenized by grinding. Aliquots were taken for elemental analysis. Samples were decarbonated using $0.1 \mathrm{~mol} \mathrm{~L}^{-1} \mathrm{HCl}$ solution. Total organic carbon (TOC) and nitrogen were measured using a Carlo Erba EA1110 CHNS-O analyzer after being centrifuged, washed with deionized water and gently dried at $60{ }^{\circ} \mathrm{C}$. Samples from all stations were collected for granulometric analysis following the procedure described by Suguio (1973).

PHYSICO-CHEMICAL PARAMETERS

Both $\mathrm{pH}$ and redox potentials (Eh) were measured using a portable instrument Ysi F-1100. The $\mathrm{pH}$ electrode was calibrated using 4.02 and 7.00 standards and measured in situ, using an $\mathrm{Ag} / \mathrm{AgCl}$ electrode, by inserting the probes directly into different sections of the sample $(1,3$ and $5 \mathrm{~cm}$ from the surface). The $\mathrm{mV}$ meter electrode was checked using deionized water. The electrodes were equilibrated over several minutes before taking a reading to be thoroughly washed and subsequently rubbed with fine emery paper after each measurement in order to prevent their poisoning by sulphide ions. Results were converted into Eh values, by adding $202 \mathrm{mV}$ to the original values read $\left(\mathrm{AgCl}\right.$ reference electrode, $\left.25^{\circ} \mathrm{C}\right)$. 


\section{EXTRACTION AND FRACTIONATION}

The processes of extraction, separation and subsequent identification of compounds were based on the procedures developed by Goossens et al. $(1989 \mathrm{a}, \mathrm{b})$ as schematically illustrated in Figure 2. The freeze-dried sediment samples weighing about $5 \mathrm{~g}$ were extracted with a mixture of $\mathrm{CH}_{2} \mathrm{Cl}_{2}: \mathrm{CH}_{3} \mathrm{OH}(2: 1, \mathrm{v} / \mathrm{v}, 3 \mathrm{x})$ by ultra-sound for $30 \mathrm{~min}$ each. In order to remove elemental sulfur, activated copper was added. The leaves were submitted to the same process except for the removal of elemental sulfur. The extracts obtained were rotary evaporated and dried over a stream of nitrogen. An aliquot of this extract (E1) was derivatized with acetyl chloride in methanol to convert fatty acids into their methyl esters.

Subsequently, very polar compounds were removed through a Pasteur pipette minicolumn over silica gel with ethyl acetate as the eluent. The eluate was evaporated with a stream of nitrogen. This fraction was dissolved with bis(-trimethylsilyl) trifluroacetamide (BSTFA). This mixture was heated $\left(60{ }^{\circ} \mathrm{C} ; 60 \mathrm{~min}\right)$ to convert alcohols into their corresponding trimethylsilyl ethers. The compounds were analyzed by means of gas chromatography-flame ionization (GC-FID) and gas chromatography-mass spectrometry (GC-MS).

After extraction the dried residues (R1) and the remaining aliquot of the underivatized extract (E1) were saponified with a $1.0 \mathrm{~mol} \mathrm{~L}^{-1}$ solution of $\mathrm{KOH}$ in $\mathrm{MeOH}: \mathrm{H}_{2} \mathrm{O}$ (96:4) for $1 \mathrm{~h}$. After cooling to room temperature, the mixture was acidified with 2.0 mol L-1 $\mathrm{HCl}: \mathrm{CH}_{3} \mathrm{OH}(1: 1)$ to $\mathrm{pH} 3.5$, centrifuged and transferred to a separation funnel. The residues were washed subsequently with $\mathrm{CH}_{3} \mathrm{OH} / \mathrm{H}_{2} \mathrm{O}$, $\mathrm{CH}_{3} \mathrm{OH}$ and $\mathrm{CH}_{2} \mathrm{Cl}_{2}$. At each time the supernatants were transferred to the separation funnel. Water was added for a better separation of the $\mathrm{CH}_{2} \mathrm{Cl}_{2}$ layer. The $\mathrm{MeOH} / \mathrm{H}_{2} \mathrm{O}$ layers were washed with $\mathrm{CH}_{2} \mathrm{Cl}_{2}$ (x2).

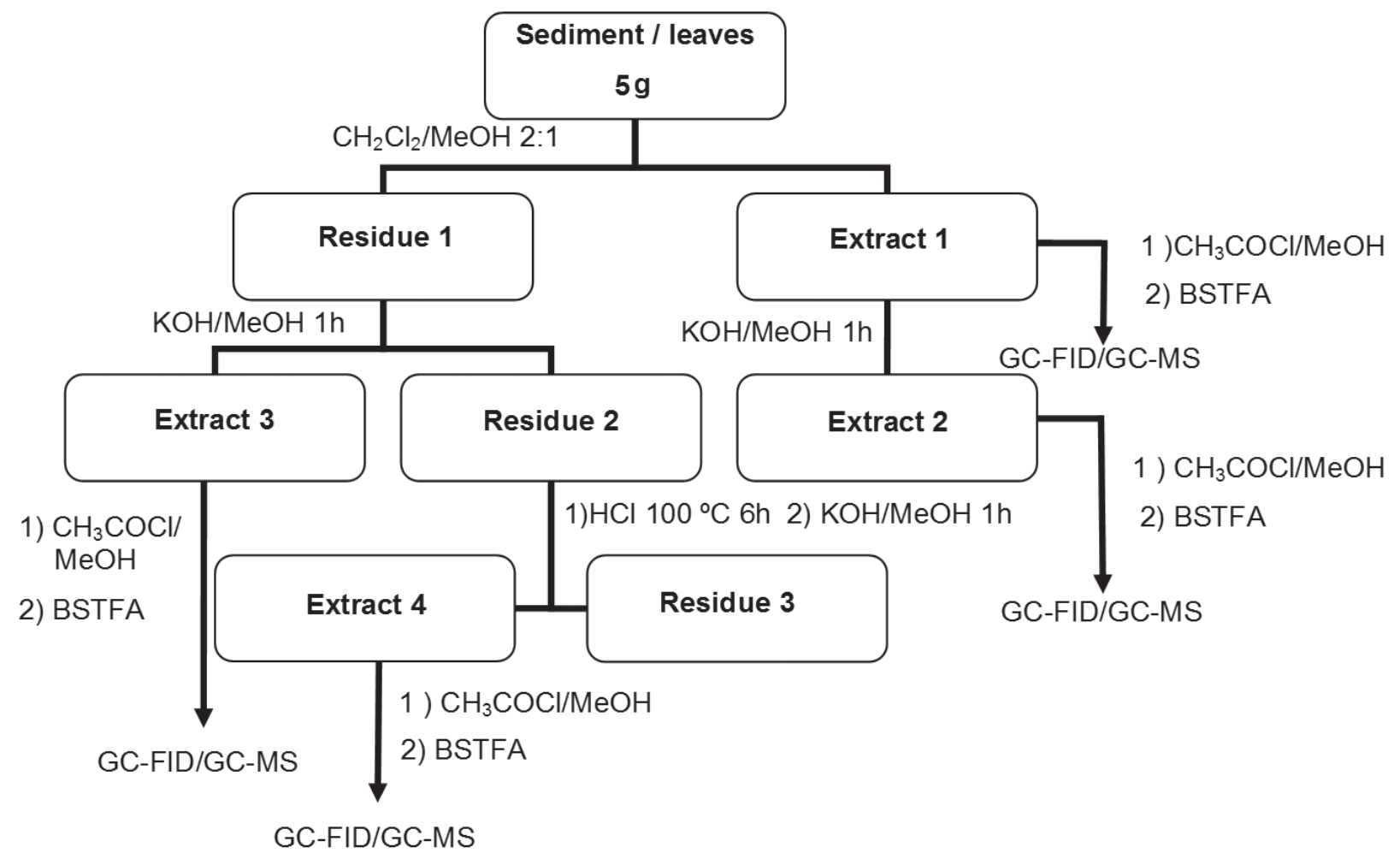

Figure 2 - Flow chart of the analytical scheme used to obtain the lipid fractions. 
The combined $\mathrm{CH}_{2} \mathrm{Cl}_{2}$ phases were concentrated using rotary evaporation, dried over anhydrous sodium sulfate and derivatized as described above, providing the extracts E2 and E3 (Figure 2).

The dried residues after saponification (R2) were also treated with a $4.0 \mathrm{~mol} \mathrm{~L}^{-1} \mathrm{HCl}$ solution $\left(6 \mathrm{~h} ; 100{ }^{\circ} \mathrm{C}\right)$. After cooling, the reaction mixture was neutralized with a $4.0 \mathrm{~mol} \mathrm{~L}^{-1}$ solution of $\mathrm{KOH}$ to $\mathrm{pH} 8.5$, freeze-dried and saponified. The extracts (E4) were washed, separated and derivatized as described above.

The four fractions were isolated to obtain the lipids in the different forms in which they are found in the organic matter. The lipid fraction (E1), or total extract, includes the lipid compounds not linked to the biopolymers. The "OH-labile" fraction (E2 and E3), released from the solvent-extracted sediments by saponification (alkaline hydrolysis), supplied the acid-linked lipids in the ester form. The extract E4 was obtained after the saponification step via acid followed by alkaline hydrolysis, thus referring to the "H-labile" fraction linked to the acids through amide and/or ether groups.

The GC-MS analysis was carried out on a Shimadzu QP5050A MS interfaced to a model 17A Shimadzu network system quadrupole GC, using electron ionization mode (electron energy $70 \mathrm{eV}$, ion source temperature $290{ }^{\circ} \mathrm{C}$, scanning from 50 to $550 \mathrm{~m} / \mathrm{z}, 2 \mathrm{scan} \mathrm{s}^{-1}$ ), a $30 \mathrm{~m}$ x $0.25 \mathrm{~mm}$ i.d. capillary column coated with $0.25 \mu \mathrm{m}$ film of DB-5MS, He as the carrier gas and an oven programmed from $70{ }^{\circ} \mathrm{C}$ (hold for $4 \mathrm{~min}$ ) to $130{ }^{\circ} \mathrm{C}$ at $20{ }^{\circ} \mathrm{C} \mathrm{min}^{-1}$, from 130 to $310^{\circ} \mathrm{C}$ at $15^{\circ} \mathrm{C} \mathrm{min}{ }^{-1}$, with a $15 \mathrm{~min}$ isotherm at $310{ }^{\circ} \mathrm{C}$. Compounds were identified based on their mass spectra, GC retention times, authentic standards (cholesterol, $\beta$-sitosterol, stigmasterol, $\alpha$-cholestane, $\beta$-amyrin from SigmaAldrich; mixes of linear $n$-alkanes and fatty acids from AccuStandards), terpenols isolated from plants (provided by other researchers) and comparison with library mass spectra. Compounds were quantified based on the total ion current peak area of the individual compounds and the relative response to the internal standards added and converted to mass based on the dry weight of the extracts.

\section{RESULTS AND DISCUSSION}

ELEMENTAL COMPOSITION AND GEOCHEMICAL PARAMETERS

Bulk sediment parameters, molar ratios and the redox conditions for all locations are listed in Table I. The content of silt plus clay ranged between 87.3 and $98.1 \%$. According to the Shepard's triangular diagram (Shepard 1954), these sediments can be classified as silted-clay. TOC values were higher in the intertidal sediment samples (ITA2 and ITA3: 4.27 and 3.32\%, respectively), which may be due to the direct contribution of leaves from mangrove trees. These results are in agreement with the greater extractable organic matter (EOM) concentrations obtained in the dry sediments of these stations (ITA2 and ITA3: 16.60 and $13.54 \mathrm{mg}$ $\mathrm{g}^{-1}$ sed. dry weight, respectively). However, as will be discussed in the next paragraph, the percentage of nitrogen also increased at both stations (ITA2 and ITA3) and the organic carbon:nitrogen ratio remained very low. Despite the TOC variation, the range of values found in the sediments is consistent with those previously reported for this mangrove region (Mater et al. 2004) and for other subtropical lagoons and estuaries (Koch et al. 2003).

The $\mathrm{C} / \mathrm{N}$ molar ratios calculated for the mangrove leaves varied from 22.1 to 26.4 and are characteristic of terrigenous plants (Table I). However, the $\mathrm{C} / \mathrm{N}$ ratios were much lower in the sediments, ranging from 7.2 at station ITA4 to 10.4 at ITA1. These are typical values corresponding to the marine organic matter contribution and indicate that the organic carbon from the mangrove leaves has been considerably remineralized or mixed with the marine organic matter. In fact, a previous work has reported that $\mathrm{C}: \mathrm{N}$ ratios in mangrove soils under $R$. mangle and A. schaueriana averaged 
TABLE I

Bulk sediment parameters and molar ratios in the Itacorubi mangrove stations.

\begin{tabular}{cccccccc}
\hline $\begin{array}{c}\text { Stations and } \\
\text { mangrove species }\end{array}$ & $\begin{array}{c}\text { Silt + clay } \\
(\%)\end{array}$ & TOC (\%) & $\mathrm{N}(\%)$ & $\mathrm{H}(\%)$ & $\mathrm{C} / \mathrm{N}$ & $\mathrm{C} / \mathrm{H}$ & $\begin{array}{c}\mathrm{EOM} \\
\left(\mathrm{mg} \mathrm{g}^{-1}\right)\end{array}$ \\
\hline ITA1 & 96.8 & 2.04 & 0.22 & 1.20 & 9.27 & 0.15 & 3.40 \\
ITA2 & 89.1 & 4.27 & 0.41 & 1.66 & 10.41 & 0.12 & 16.60 \\
ITA3 & 87.3 & 3.32 & 0.40 & 1.59 & 8.30 & 0.10 & 13.54 \\
ITA4 & 98.1 & 1.86 & 0.26 & 1.47 & 7.15 & 0.21 & 1.08 \\
Avic & & 41.94 & 1.90 & 5.92 & 22.07 & 0.59 & \\
Lagun & & 45.17 & 1.71 & 5.62 & 26.42 & 0.63 & \\
Spar & & 39.69 & 1.52 & 5.51 & 26.11 & 0.62 & \\
Rhiz & & 45.42 & 1.82 & 6.41 & 24.96 & 0.67 & \\
\hline
\end{tabular}

TOC: total organic carbon.

EOM: Extractable organic matter ( $\mathrm{mg} \mathrm{g}^{-1}$ of dry weight sediment)

Values shown are the average of three replicate analyses with RSD $<3.8 \%$.

near 17 (Lacerda et al. 1995). The $\mathrm{C} / \mathrm{H}$ molar ratio also indicated this depletion of organic carbon (Table I). The calculated $\mathrm{C} / \mathrm{H}$ values were 0.59 0.67 in the leaves and decreased to $0.10-0.21$ in the sediments possibly due to a partial loss of carbon and hydrogenation of the organic material.

The redox conditions were measured at three depths $(1,3$ and $5 \mathrm{~cm})$ at the locations where the sediment samples were collected. With the exception of station ITA1 (first centimeter), all values were negative (ranging from -444 to -250 $\mathrm{mV}$ ), representing very reducing conditions (Baltzer 1982, Lallier-Vergès et al. 1998).

\section{BIOMARKERS IN LEAVES AND SEDIMENTS}

In this section we will discuss data on the $n$-alkane, monocarboxylic and hydroxy fatty acids, sterol and triterpenol concentrations and the distribution patterns of individual compounds in the surface sediments and leaves of the mangrove species. In terms of hydrocarbon distribution, total $n$-alkanes
$\left(\mathrm{C}_{22}-\mathrm{C}_{33}\right)$ showed a predominance of compounds with odd carbon numbers, mainly in the leaf samples. For the sediments, the total concentration was highest at station ITA3 (34.6 $\mu \mathrm{g} \mathrm{g}^{-1}$ of extractable organic matter - EOM) and the lowest value was found at station ITA4 (27.5 $\left.\mu \mathrm{g} \mathrm{g}^{-1} \mathrm{EOM}\right)$, with a maximum peak for $\mathrm{C}_{29}$, typically found in terrigenous plants. The highest concentrations of hydrocarbons were detected in the leaf sample of Avicennia $\left(38.8 \mu \mathrm{g} \mathrm{g}^{-1}\right.$ of dry leaf-DL). In contrast, the lowest value was found in the Gramineae sample $\left(8.8 \mu \mathrm{g} \mathrm{g}^{-1} \mathrm{DL}\right)$, which is nearly 4.4 times lower than that of Avicennia. The lower concentration of hydrocarbons in S. alterniflora can be explained because it is a non- vascular plant species with lower cellulose and lignin contents.

The Carbon Preference Index (CPI) was calculated in the range of $\mathrm{C}_{23}-\mathrm{C}_{31}$ for $n$-alkanes, and the results showed CPI $>2$ for the sediments, which indicates a large contribution from terrigenous particulate material (Table II). For comparison, CPI values of hydrocarbons from 
the leaf samples were also calculated. The highest value was obtained for Laguncularia (CPI $=11.2$ ), with $n-\mathrm{C}_{29}$ concentration nearly three times higher than that of $n-\mathrm{C}_{27}$.

With respect to total monocarboxylic acids, the distribution in the sediment samples ranged from $\mathrm{C}_{10}$ to $\mathrm{C}_{32}$ for the linear compounds. Long-chain components with an even-over-odd distribution are characteristic of contributions from higher plants. Several monounsaturated and isoprenoic acids were also detected (Table II). In the leaf samples the major compounds were a few monocarboxylic acids, with the predominance of $\mathrm{C}_{16}$ and $\mathrm{C}_{18} . A$. schaueriana (black mangrove) mainly contained $\mathrm{C}_{16}$ monocarboxylic acid $\left(87.5 \mu \mathrm{g} \mathrm{g}^{-1} \mathrm{DL}\right)$ with a very low amount of $\mathrm{C}_{18}\left(0.7 \mu \mathrm{g} \mathrm{g}^{-1} \mathrm{DL}\right)$, whereas the mangrove species $L$. racemosa (white mangrove) showed the highest values for $\mathrm{C}_{16}$ and $\mathrm{C}_{18}$ (159.9 and $120.6 \mu \mathrm{g} \mathrm{g}^{-1} \mathrm{DL}$, respectively) and also a very high content of the $\mathrm{C}_{18: 3}$ fatty acid $\left(206.5 \mu \mathrm{g} \mathrm{g}^{-1}\right.$ DL). The latter compound was not detected in any of the mangrove sediment samples, possibly due to the instability of this compound leading to its rapid oxidation.

Several monounsaturated fatty acids were identified in the sediment samples, but none of them was seen in the leaf samples. These compounds are probably produced by microorganisms, since most bacteria do not contain fatty acids with more than one $\mathrm{C}=\mathrm{C}$ bond. Significant quantities of the acids $\mathrm{C}_{16: 1}, \mathrm{C}_{18: 1}, \mathrm{C}_{19: 1}$, and $\mathrm{C}_{22: 1}$ appeared predominantly (Table II), with both cis and trans configurations. Both $\mathrm{C}_{16: 1}$ and $\mathrm{C}_{18: 1}$ are found in recent sediments and are often used to differentiate between isomers predominantly derived from bacteria $\left(\omega^{7}\right)$ and algae $\left(\omega^{9}\right)$ (Killops and Killops 2005). As described in Table II, other isomers were also detected and are usually associated with bacteria ( $\omega^{10}$ isomers).

Hydroxy acids were obtained only from the labile acid fraction. Their biological formation is characterized by a high diversity of sources. For example, medium chain length $\left(\mathrm{C}_{12}-\mathrm{C}_{18}\right)$, iso- and anteiso-branched $\beta$-hydroxy acids are produced by various bacteria, microalgae and seagrasses (Garcette-Lepecq et al. 2004 and references therein). The medium and long chain $\left(\mathrm{C}_{16}-\mathrm{C}_{30}\right) \alpha$-hydroxy acids can be related to microalgae and bacteria whereas $\omega$-hydroxy acids, medium and long chain, are major components of cutins, suberins and higher plant epicuticluar waxes (Garcette-Lepecq et al. 2004 and references therein).

The hydroxy acids identified in the four sediment samples are dominated by saturated compounds, with the highest percentage of $\omega-\mathrm{C}_{16}$ $(37.0 \%)$ and $\omega-\mathrm{C}_{18}(38.9 \%)$ at stations ITA2 and ITA1, respectively (Table III). In spite of being reported in the literature as components of terrigenous plants, saturated $\omega$-hydroxy acids were not identified in the mangrove leaf samples, with the exception of two hydroxy acids containing more than one hydroxyl group: $\omega-\mathrm{C}_{16}(9,10,16$-trihydroxy acid) and $\omega-\mathrm{C}_{18}$ (9,10,16-trihydroxy acid); and one unsaturated $\omega-\mathrm{C}_{18: 1}$ hydroxy acid. The $\omega-\mathrm{C}_{16}$ 9,10,16-trihydroxy acid showed the highest percentage of all the hydroxy acids in two mangrove species (Avicennia and Laguncularia) and the Gramineae Spartinna (see top mass chromatogram on Figure 3). The appearance of $\omega$-hydroxy acids only in the sediments can be indicative of bacterial $\omega$-oxidation of alkylchains, as previously reported in decomposing eelgrasses Zostera marina L. by de Leeuw et al. (1995). No $\omega$-hydroxy acids were detected in the living eelgrass free and bound fractions investigated by the authors. For the $\alpha$-hydroxy acid distribution no clear even-over-odd carbon number predominance was observed (see bottom mass chromatogram on Figure 3). The $\alpha-\mathrm{C}_{24}$ hydroxy acid was the major compound identified in the leaf samples, accounting for $37.7 \%$ in the leaves of the Rhizophora mangle. Previous studies on soil and surface sediments from Lake Ahmasrjävi in Finland have suggested that part of the $\alpha$-hydroxy acids may originate from Gram-positive bacteria and other microbial groups (Keinänen et al. 2003). 
TABLE II

Overview of the relative quantities of total $\boldsymbol{n}$-alkanes, monocarboxylic saturated fatty acids, individual iso ( $i$ - $\mathrm{C}_{\mathrm{x}}$ ), anteiso $\left(\right.$ ai- $\mathrm{C}_{\mathrm{x}}$ ), unsaturated fatty acids and sterols in all sediment and leaf samples. CPI: Carbon Preference Index calculated in the $\mathrm{C}_{22}-\mathrm{C}_{32} n$-alkane range. Values shown are the average of duplicate analyses.

\begin{tabular}{|c|c|c|c|c|c|c|c|c|}
\hline \multirow[b]{2}{*}{ Compound } & \multicolumn{4}{|c|}{ Stations $\left(\mu \mathrm{g} \mathrm{g}^{-1} \mathrm{EOM}\right)^{\mathrm{a}}$} & \multicolumn{4}{|c|}{ Mangrove Leaf $\left(\mu \mathrm{g} \mathrm{g}^{-1} \mathrm{DL}\right)^{\mathrm{b}}$} \\
\hline & ITA1 & ITA2 & ITA3 & ITA4 & Avic & Lagun & Spar & Rhiz \\
\hline$a i-\mathrm{C}_{14}$ & -- & -- & -- & -- & 0.7 & 0.9 & 0.9 & 0.9 \\
\hline$a i-\mathrm{C}_{14} 5,9,13$ & 1.1 & 0.6 & 43.8 & -- & -- & -- & -- & -- \\
\hline$i-\mathrm{C}_{14}$ & 7.8 & 5.5 & -- & 5.2 & -- & -- & -- & -- \\
\hline$a i-\mathrm{C}_{15}$ & 7.3 & 9.6 & 7.7 & 18.7 & -- & -- & -- & -- \\
\hline$i-\mathrm{C}_{15}$ & 3.5 & 2.2 & 6.7 & 2.3 & -- & -- & -- & -- \\
\hline$n-\mathrm{C}_{16: 1} \omega 7$ - cis & 1.7 & -- & -- & -- & -- & -- & -- & -- \\
\hline$n-\mathrm{C}_{16: 1} \omega 7-\operatorname{trans}$ & 0.8 & 2.3 & -- & 3.4 & -- & -- & -- & -- \\
\hline$n-\mathrm{C}_{16: 1} \omega 9$ - cis & 7.3 & 0.4 & -- & 2.9 & -- & -- & -- & -- \\
\hline$a i-\mathrm{C}_{16}$ & 4.5 & 2.6 & -- & 3.9 & -- & -- & -- & -- \\
\hline$i-\mathrm{C}_{16}$ & -- & -- & 5.1 & -- & -- & -- & -- & -- \\
\hline$a i-\mathrm{C}_{17}$ & 5.1 & 1.8 & -- & 1.7 & -- & -- & -- & -- \\
\hline$i-\mathrm{C}_{17}$ & 1.5 & 8.2 & -- & 1.1 & -- & -- & -- & -- \\
\hline$n-\mathrm{C}_{18: 3}-\operatorname{trans}$ & -- & -- & -- & -- & 1.7 & 206.5 & 22.0 & 6.3 \\
\hline$n-\mathrm{C}_{18: 1} \omega 10$ & 6.7 & 3.6 & -- & 49.7 & -- & -- & -- & -- \\
\hline$n-\mathrm{C}_{18: 1} \omega 15$ & 8.0 & 4.6 & 5.9 & 31.1 & -- & -- & -- & -- \\
\hline$n-\mathrm{C}_{18: 1} \omega 19$-cis & 1.3 & 0.4 & -- & 1.3 & -- & -- & -- & -- \\
\hline$a i-\mathrm{C}_{18}$ & 6.7 & 5.7 & -- & 4.7 & -- & -- & -- & -- \\
\hline$n-\mathrm{C}_{19: 1} \omega 10$ & 2.5 & -- & -- & -- & -- & -- & -- & -- \\
\hline$n-\mathrm{C}_{19: 1} \omega 10$ & 2.1 & 0.9 & -- & -- & -- & -- & -- & -- \\
\hline$n{ }^{n}{ }_{\mathrm{C} 19: 1} \omega 11$ & 2.5 & 0.7 & -- & 1.8 & -- & -- & -- & -- \\
\hline$n^{n-\mathrm{C} 22: 1}{ }_{1} \omega 13$-cis & 1.7 & 0.5 & -- & 2.6 & -- & -- & -- & -- \\
\hline$n-\mathrm{C}_{22: 1} \omega 13$-trans & 3.2 & -- & -- & 1.6 & -- & -- & -- & -- \\
\hline Ealiphatic ${ }^{\mathrm{d}}$ & 29.5 & 27.9 & 34.6 & 27.5 & 38.8 & 26.9 & 8.8 & 24.6 \\
\hline $\mathrm{CPI}^{\mathrm{e}}$ & 3.1 & 2.8 & 1.8 & 3.1 & 6.6 & 11.2 & 3.4 & 2.2 \\
\hline$\sum$ sat. $\operatorname{acids}^{\mathrm{f}}$ & 87.3 & 107.3 & 40.9 & 315.8 & 126.9 & 330.3 & 524.5 & 394.8 \\
\hline
\end{tabular}

${ }^{\mathrm{a}} \mu \mathrm{g} \mathrm{g}{ }^{-1}$ of extractable organic matter; ${ }^{\mathrm{b}} \mu \mathrm{g} \mathrm{g}{ }^{-1}$ of dry leaf; ${ }^{\mathrm{c}}(--)$ below detection limit

${ }^{\mathrm{d}}$ aliphatic hydrocarbons: $n-\mathrm{C}_{22}-\mathrm{C}_{32}+$ Pristane+Phytane; ${ }^{\mathrm{e}} \mathrm{CPI}$ (Carbon Preference Index) $=2\left(n \mathrm{C}_{23}+n \mathrm{C}_{25}+n \mathrm{C}_{27}+n \mathrm{C}_{29}+n \mathrm{C}_{31}\right) /\left[\left(n \mathrm{C}_{22}+n \mathrm{C}_{24}+n \mathrm{C}_{26}\right.\right.$

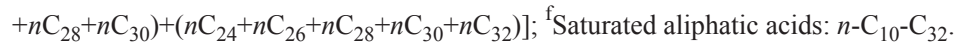

These authors also showed that $\alpha$-hydroxy acids with a chain length greater than 14 were generally more abundant in the sediment than in the soil. Two hydroxy acids, $\mathrm{C}_{16}$ and $\mathrm{C}_{24}$, appeared predominantly. Another study on surface sediments from the Danube delta has also shown that $\alpha-C_{24}$ hydroxy acid was the most abundant (Garcette-Lepecq et al. 2004). It is interesting to notice that these compounds are usually related to microbial sources and to biomass, but not specifically to leaves.

All sterols detected in the surface samples and leaf extracts are described below. Their 
identifications were based on their mass spectra, In the sediments, sterols are composed mainly relative retention times, comparison with authentic of $\mathrm{C}_{27}$ and $\mathrm{C}_{29}$ components, which account for standards and key fragment ions of TMS derivatives: $m / z 129$ for $\mathrm{C}_{27}-\mathrm{C}_{29} \Delta^{5}$ and $\Delta^{5,22}$ components; $m / z$ 251 for $\mathrm{C}_{27}-\mathrm{C}_{29} \Delta^{0}$; and $m / z 257$ for $\mathrm{C}_{27}-\mathrm{C}_{29} \Delta^{22}$. $33.2 \%$ and $45.6 \%$, respectively. The $\mathrm{C}_{27}$ sterols

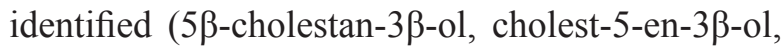
$5 \alpha$-cholestan- $3 \beta$-ol, and one stanone: $5 \alpha$-cholest-
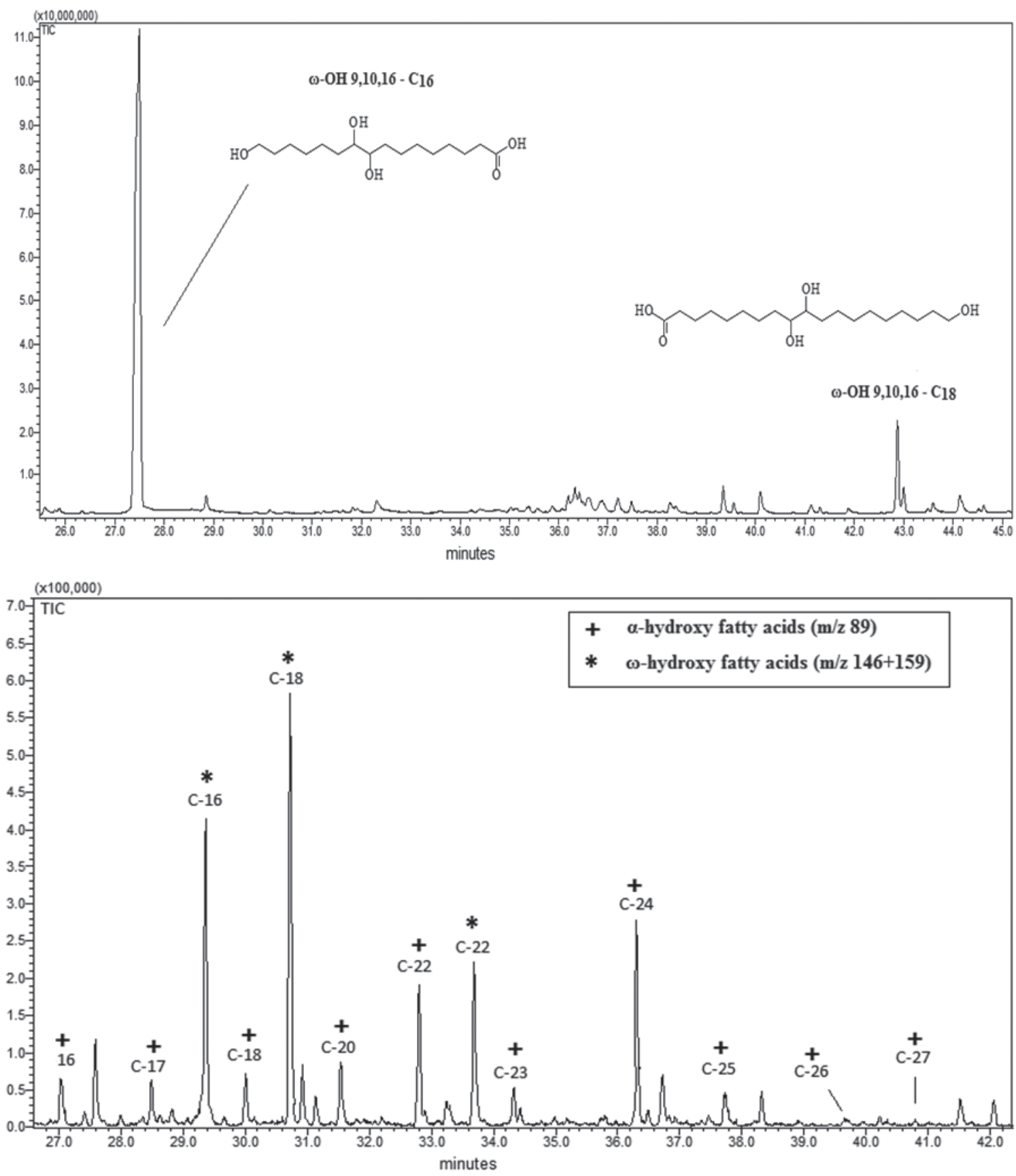

Figure 3 - Partial mass chromatogram (TIC) of the extract (E4) obtained from the leaf extract of Avicennia (top). Partial mass chromatogram (TIC) and the main fragments employed to identify the $\alpha$ - and $\omega$-hydroxy fatty acids as methyl esters from the extract (E4) of the ITA1 sediment (bottom). 
TABLE III

Relative abundance (\%) of hydroxy fatty acids obtained from the "acid fraction" via sequential treatment.

\begin{tabular}{|c|c|c|c|c|c|c|c|c|}
\hline \multirow[b]{2}{*}{ Compound } & \multicolumn{4}{|c|}{ Stations } & \multicolumn{4}{|c|}{ Mangrove Leaf } \\
\hline & ITA1 & ITA2 & ITA3 & ITA4 & Avic & Lagun & Spar & Rhiz \\
\hline$\alpha-\mathrm{OH} \mathrm{C} \mathrm{C}_{16}$ & 1.69 & 12.46 & 10.73 & $--^{*}$ & -- & -- & -- & -- \\
\hline$\alpha-\mathrm{OH} \mathrm{C} \mathrm{C}_{17}$ & 1.84 & 3.35 & 13.03 & 17.74 & -- & -- & -- & -- \\
\hline$\alpha-\mathrm{OH} \mathrm{C} \mathrm{C}_{18}$ & 2.46 & 3.76 & 0.42 & 4.74 & -- & -- & -- & -- \\
\hline$\alpha-\mathrm{OH} \mathrm{C} \mathrm{C}_{20}$ & 2.20 & 4.27 & 3.83 & 21.47 & 7.06 & 2.66 & 13.83 & 9.06 \\
\hline$\alpha-\mathrm{OH} \mathrm{C} \mathrm{C}_{22}$ & 2.25 & 5.69 & -- & 8.18 & 0.21 & -- & -- & -- \\
\hline$\alpha-\mathrm{OH} \mathrm{C} \mathrm{C}_{23}$ & 2.30 & 2.00 & 2.43 & 17.90 & 6.82 & 4.53 & 7.86 & 9.54 \\
\hline$\alpha-\mathrm{OH} \mathrm{C} \mathrm{C}_{24}$ & 8.62 & 5.09 & 7.71 & 7.03 & 12.36 & 8.09 & 17.76 & 37.73 \\
\hline$\alpha-\mathrm{OH} \mathrm{C} \mathrm{C}_{25}$ & 1.81 & 2.13 & -- & -- & -- & 4.39 & 3.39 & 7.99 \\
\hline$\alpha-\mathrm{OH} \mathrm{C} \mathrm{C}_{26}$ & 0.15 & 0.80 & -- & 14.60 & 0.64 & 1.45 & 4.90 & 4.22 \\
\hline$\alpha-\mathrm{OH} \mathrm{C} \mathrm{C}_{27}$ & 0.93 & 4.34 & 0.46 & 6.21 & -- & -- & -- & -- \\
\hline$\omega-\mathrm{OH} \mathrm{C}$ & 33.16 & 37.04 & 29.78 & 1.06 & -- & -- & -- & -- \\
\hline$\omega-\mathrm{OH} \mathrm{C} \mathrm{C}_{18}$ & 38.94 & 9.00 & 22.74 & 0.75 & -- & -- & -- & -- \\
\hline$\omega-\mathrm{OH} \mathrm{C} 22$ & 3.65 & 10.07 & 8.89 & 0.32 & -- & -- & -- & -- \\
\hline$\omega-\mathrm{OH} 9,10,16-\mathrm{C}_{16}$ & -- & -- & -- & -- & 69.75 & 78.76 & 50.87 & -- \\
\hline$\omega-\mathrm{OH} 9,10,16-\mathrm{C}_{18}$ & -- & -- & -- & -- & 3.16 & 0.11 & -- & 2.58 \\
\hline$\omega-\mathrm{OH} \mathrm{C} \mathrm{C}_{18: 1}$ & -- & -- & -- & -- & -- & -- & -- & 28.87 \\
\hline
\end{tabular}

* ( -- ) Below detection limit

8-en-3-one) are usually associated with sewage, microbes or other marine sources since they are not commonly found in higher plant waxes (Grimalt et al. 1990). Compounds that are generally employed as fecal pollution indicators, coprostanol

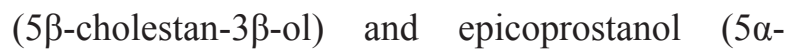
cholestan-3 $\beta$-ol), are the major components of $\mathrm{C}_{27}$ sterols in most of the surface samples analyzed, with average values of 7.6 and $7.8 \mu \mathrm{g} \mathrm{g}^{-1} \mathrm{EOM}$, respectively (Table IV). For both compounds, the highest concentrations were found at station ITA2 $\left(11.1 \mu \mathrm{g} \mathrm{g}^{-1}\right.$ EOM and $12.0 \mu \mathrm{g} \mathrm{g}^{-1}$ EOM for coprostanol and epicoprostanol, respectively). According to the literature, concentrations of coprostanol greater than $9 \mu \mathrm{g} \mathrm{g}^{-1}$ are characteristic of sediments contaminated with sewage discharge (Nichols and Leeming 1991). However, it is important to mention that some authors have already emphasized that coprostanol can be found in algae (Grimalt et al. 1990, Colombo et al. 1996) and also the reduction of $\Delta^{5}$ sterols in sediments usually produces stanol mixtures where $5 \alpha$-epimers are dominant (Fernandes et al. 1999). Nonetheless, using the $(5 \beta / 5 \beta+5 \alpha)$ stanol ratio proposed by Grimalt et al. (1990) for sewage pollution identification, we found ratios ranging from 0.30 to 0.58 (stations ITA4 and ITA1, respectively) for the sediments of Itacorubi (Table IV). Values for this ratio higher than 0.70 are considered to be indicative of significant sewage contamination (Grimalt et al. 1990, Carrera et al. 2001). In a previous study on the Itacorubi mangrove, we found values between 0.64 and 0.82 for river sediments receiving sewage discharges (Mater et al. 2004). These previous results suggest a higher level of contamination in the river sediments and, to a lesser extent, in the sediments of the mangrove located within the intertidal zone. 
TABLE IV

Concentration and ratios of sterols.

\begin{tabular}{|c|c|c|c|c|c|c|c|c|}
\hline \multirow{2}{*}{$\begin{array}{c}\text { Stations }\left(\mu \mathrm{g} \mathrm{g}^{-1} \mathrm{EOM}\right) \\
\text { Compound }\end{array}$} & \multicolumn{8}{|c|}{ Mangrove Leaf ( $\left.\mu \mathrm{g} \mathrm{g}^{-1} \mathrm{DL}\right)$} \\
\hline & ITA1 & ITA2 & ITA3 & ITA4 & Avic & Lagun & Spar & Rhiz \\
\hline $5 \alpha$-cholestan- $3 \beta$-ol & 7.7 & 12.0 & 6.9 & 4.4 & 4.4 & -- & -- & -- \\
\hline $5 \beta$-cholestan-3 $\beta$-ol & 10.7 & 11.1 & 6.6 & 1.9 & 1.9 & -- & -- & -- \\
\hline 5-cholesten-3 $\beta$-ol & 3.5 & 2.7 & 13.4 & 0.8 & 0.8 & -- & -- & -- \\
\hline $5 \alpha$-cholest- 8 -en-3-one & 3.0 & 5.9 & 15.4 & 5.0 & 5.0 & -- & -- & -- \\
\hline 24-methyl-5,22-cholestadien-3 $\beta$-ol & 26.0 & 15.7 & 10.7 & 12.0 & 12.0 & -- & -- & 2.1 \\
\hline $24 \alpha$-ethyl-5,22-cholestadien-3 $\beta$-ol & 4.1 & 6.7 & 10.7 & 1.0 & 1.0 & 5.1 & 5.8 & 5.0 \\
\hline $24 \beta$-ethyl-5,22-cholestadien-3 $\beta$-ol & 20.2 & 7.4 & 9.6 & 4.5 & 4.5 & 5.4 & 1.0 & 4.5 \\
\hline $24 \beta$-ethyl- $5 \beta$-cholesten- $3 \beta$-ol & 7.4 & 5.1 & 23.9 & 3.0 & 3.0 & 15.0 & 29.7 & 9.6 \\
\hline $24 \beta$-ethyl- $5 \beta$-cholestan- $3 \beta$-ol & 11.3 & 16.6 & 2.2 & 5.5 & 5.5 & -- & -- & -- \\
\hline $5 \beta /(5 \beta+5 \alpha)^{\mathrm{a}}$ & 0.58 & 0.48 & 0.49 & 0.30 & 0.30 & -- & -- & -- \\
\hline
\end{tabular}

${ }^{\text {a }}$ ratio of cholestanols

The $\mathrm{C}_{29}$ phytosterols were detected in higher abundance than the $\mathrm{C}_{28}$ components. In fact, only 24-methylcholesta-5,22-dien-3 $\beta$-ol was determined, with very high concentration. A previous work with algae has shown that $C_{28}$ sterol can be found in diatoms (Barret et al. 1995). In the sediment samples, $24 \beta$-ethylcholesta-5,22-dien-3 $\beta$-ol and $24 \beta$-ethyl-5cholesten-3 $\beta$-ol are the major $\mathrm{C}_{29}$ compounds. These two compounds come mainly from terrigenous sources, but are not restricted to higher plants (Volkman 1986, Barret et al. 1995). Accordingly, in the extracts from the leaf samples only $\mathrm{C}_{28}$ and $\mathrm{C}_{29}$ were detected, with a strong predominance of $24 \beta$-ethyl-5-cholesten-3 $\beta$-ol ( $\beta$-sitosterol), varying from 9.6 to $33.5 \mu \mathrm{g} \mathrm{g}^{-1} \mathrm{DL}$. It is interesting to note the presence of the stanol 24-ethyl-5 $\beta$-cholestan$3 \beta$-ol in the sediment samples only. This compound has been previously detected in a marsh area of a mangrove ecosystem in northern Brazil (Koch et al. 2003). Stanols in sediments can originate from direct biogenetic inputs and possible mixtures of $5 \alpha$-stanols from marine organisms. Our results showed that no stanols were indentified in the leaf samples, suggesting the occurrence of a direct input from diatoms as they are likely to be found in the flooding seawater (Soriano-Sierra and Ledo 1998), or a direct reduction from the $\mathrm{C}_{29} 5$-cholesten-3 $\beta$-ol by microbially-mediated diagenetic transformation reactions in the sediments (Takahashi et al. 1985, Emeis et al. 2000).

With regard to the triterpenols identified in the leaf extracts, seven compounds appear predominantly (Figure 4). Leaves of A. schaueriana, the dominant species in the mangrove, were characterized by high amounts of $\beta$-amyrin (olean-12-en-3 $\beta$-ol; $90.6 \mu \mathrm{g} \mathrm{g}^{-1}$ DL) and lower contents of lupeol (lup-20(29)-en$3 \beta$-ol), $\alpha$-amyrin (ursen-12-en-3 $\beta$-ol), germanicol

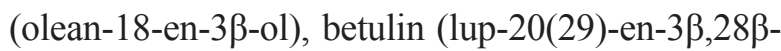
diol) and friedelin (friedelan-3-one). Laguncularia racemosa, the second most abundant adult species, was dominated by $\beta$-amyrin and lupeol, but with much lower amounts than those found in $A$. schaueriana (Figure 4). Among the triterpenes found in the sediments, $\beta$-amyrin showed the greatest decrease in the relative percentage found in the leaf extract. It seems to be the most labile molecule 
among the triterpenols. However, a previous work with an incubation experiment (Koch et al. 2005) demonstrated that all leaf-derived triterpenols can be degraded. Working with sediment samples from a northern Brazilian mangrove, the authors reported that the relative biomarker signature in the sediment predominantly represented $R$. mangle leaf litter. In our study, a simple comparison between the relative abundance of seven triterpenols showed that betulin and $\alpha$-amyrin are relatively higher in the sediments compared with the distribution in the leaf extracts. A very low amount of taraxerol $\left(1.9 \mu \mathrm{g} \mathrm{g}^{-1} \mathrm{DL}\right)$ that has been used for identifying mangrove-derived organic matter in sediments (Koch et al. 2003, Jaffé et al. 2006, Volkman et al. 2007), was only found in the leaf extract of Rhizophora mangle. However, it is well preserved when compared to $\beta$-amyrin. Taraxerol can occur in many other higher plant species, and other sources may also contribute to its increase. However, the region is strongly dominated by mangrove species and other sources are unlikely. Interesting results were found for betulin, which was only detected in the leaf extract of $A$. schaueriana (2.3 $\left.\mu \mathrm{g} \mathrm{g}^{-1} \mathrm{DL}\right)$, but increased in the sediments. Betulin has been previously reported in sediments and is a good chemotaxonomic biomarker for mangrove species.

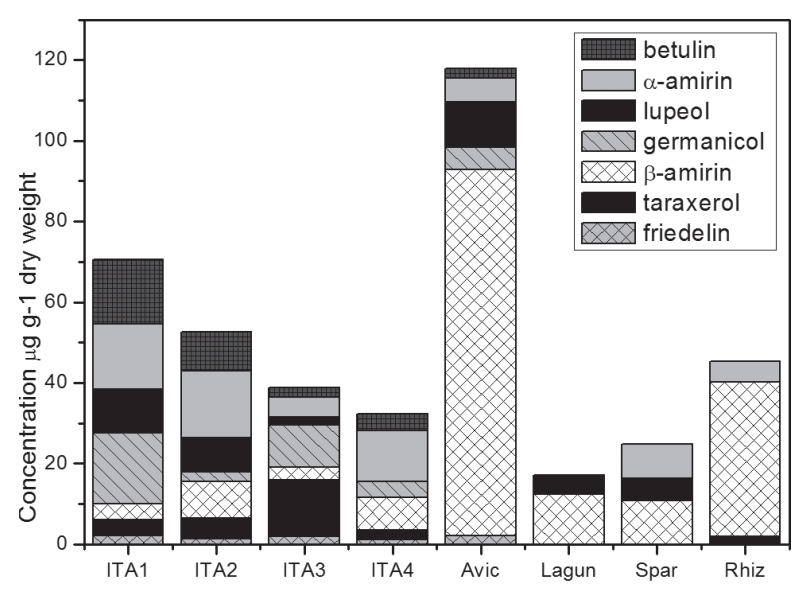

Figure 4-Relative abundance of triterpenols in the sediments and leaf extracts (Avicennia schaueriana, Laguncularia racemosa, Spartinna alterniflora and Rhizophora mangle).
The composition of lipids in the sediments and leaves showed that saturated fatty acids are the major compounds, accounting for over $35 \%$ of the total lipids identified (Figure 5). The leaves of Rhizophora mangle and Spartinna are dominated by saturated fatty acids (mainly $n \mathrm{C}_{16: 0}$ and $n \mathrm{C}_{18: 0}$ ). A high percentage of saturated fatty acids (52\%) was also detected in L. racemosa, but, in contrast to the other leaves, this species contains the highest percentage of unsaturated fatty acids $\left(n \mathrm{C}_{18: 3} ; 33 \%\right)$. The leaves of $A$. schaueriana showed the highest abundance of terpenes and sterols, comprising $33 \%$ and $17 \%$ of the total lipid concentration, respectively. Aliphatic hydrocarbons are the least abundant lipids and constitute less than $12 \%$ of the total lipids. Apart from saturated fatty acids, the sediments are dominated by sterols $(20 \%)$, which showed an increase due to the presence of $\mathrm{C}_{27}$ compounds from other sources. Terpenes are the third most abundant components $(13 \%)$, showing their importance as terrestrial biomarkers for mangrove-derived organic matter.

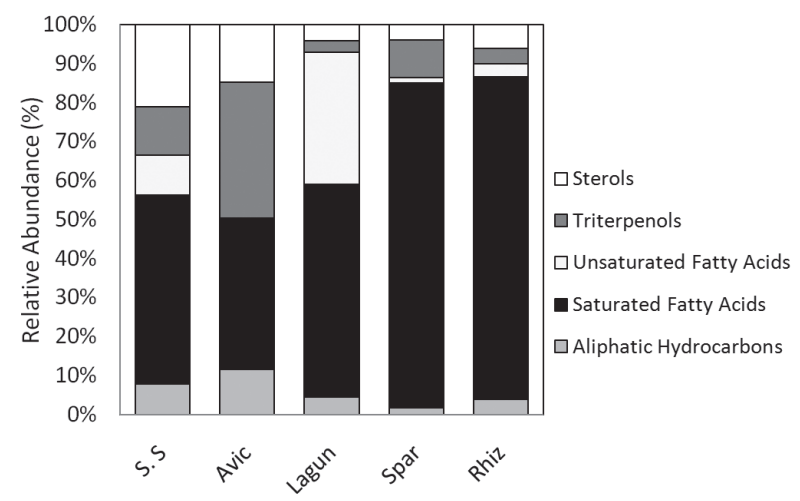

Figure 5 - Composition of lipids in the sediment samples (ss) and leaf extracts (sterols, triterpenols, unsaturated fatty acids, saturated fatty acids and aliphatic hydrocarbons).

\section{CONCLUSIONS}

The composition of lipids in the leaves revealed that sterols and triterpenols are two important groups of compounds that can be used to assess the contribution of the organic matter from mangrove leaves. Despite the changes in the relative abundance 
from the leaf extract to the sediments, triterpenols, such as germanicol, $\alpha$-amyrin, betulin and lupeol, are important biomarkers as they are well preserved in the sediments. In contrast to other terpenols, $\beta$-amirin was the most abundant triterpenol found in the plants, but it is rapidly degraded and less preserved in the sediments.

Saturated and unsaturated fatty acids cannot be exclusively correlated to mangrove input. In spite of being detected in the L. racemosa leaf, the unsaturated fatty acid $\left(n \mathrm{C}_{18: 3}\right)$ was not found in the sediments. However the $\alpha$-hydroxy acids (from $\alpha-\mathrm{OH} \mathrm{C}_{20}$ to $\mathrm{C}_{26}$ ) found in leaves and sediments are good indicators of mangrove input.

\section{ACKNOWLEDGMENTS}

Scholarship for C. A. Silva was provided by Coordenação de Aperfeiçoamento de Pessoal de Nível Superior (CAPES). Financial support was provided by Petrobras and Conselho Nacional de Desenvolvimento Científico e Tecnológico (CNPq).

\section{RESUMO}

A distribuição relativa de vários compostos identificados em quatro amostras de sedimentos recentemente depositados no manguezal do Itacorubi, localizado na Ilha de Santa Catarina, no sul do Brasil, foi comparada a dos diversos compostos extraídos de folhas frescas de três espécies de mangues: Avicennia schaueriana, espécie dominante na região, Rhizophora mangle, Laguncularia racemosa, e a gramínea Spartinna alterniflora. Terpenóis identificados previamente em espécies de mangues no norte do Brasil também foram encontrados. A espécie $A$. schaueriana contém principalmente $\beta$-amirina $(90,6 \mu \mathrm{g}$ $\mathrm{g}^{-1}$ de material orgânico extraído); pequenas quantidades de friedelina, betulina e germanicol foram detectadas somente nas folhas dessa espécie. $R$. mangle também contém uma quantidade significativa de $\beta$-amirina e foi a única espécie na qual o taraxerol foi detectado. Contrariamente ao encontrado nas folhas, nas amostras de sedimentos predominaram o germanicol, $\alpha$-amirina e campesterol. Apesar da maior labilidade, o composto betulina também foi identificado. Duas séries homólogas de $\alpha$ e $\omega$-hidroxi de ácidos graxos foram identificadas na fração ácida-alcalina. Apesar de serem relatados na literatura como componentes de plantas terrígenas, não foram identificados os $\omega$-hidroxiácidos saturados. Nossos resultados indicam que embora os terpenóis possam ser usados como biomarcadores para material orgânico proveniente de manguezais, a distribuição relativa pode variar conforme a região.

Palavras-chave: biomarcadores, folha, manguezal, Santa Catarina, sedimento.

\section{REFERENCES}

BALTZER F. 1982. La transition eau douce-eau salée dans lês mangroves. Conséquences sédimentologiques et géochimiques. B Soc Geol Fr 144: 27-42.

BARRET SM, VOLKMAN JK, DUNSTAN GA AND LEROI J-M. 1995. Sterols of 14 species of marine diatoms (Bacillariophyta). J Phycol 31: 360-369.

Boulllon S, Dahdouh-Guebas F, Rao AVVS, Koedam N AND DEHAIRS F. 2003. Sources of organic carbon in mangrove sediments: variability and possible implications for ecosystem functioning. Hydrobiologia 495: 33-39.

CARRERA R, WAGENER ALR, FILEMAN T AND READMAN JW. 2001. Distribuição de coprostanol $(5 \beta(H)$-colestan- $3 \beta$ ol) em sedimentos superficiais da Baía de Guanabara: indicador da poluição recente por esgotos domésticos. Quim Nova 24: 37-42.

Colombo JC, Silverberg N AND Gearing JN. 1996. Lipid biogeochemistry in the Laurentian Trough: I-fatty acids, sterols and aliphatic hydrocarbons in rapidly settling particles. Org Geochem 25: 211-225.

De LeEUW JW AND LARGEAU CA. 1993. A review of macromolecular organic compounds that comprise living organisms and their role in kerogen, coal and petroleum formation. In: Engel MH and Macko SA (Eds), Organic Geochemistry Principles and Applications, Plenum: New York, USA, p. 23-72.

DE LEEUW JW, RIJPSTRA WIC AND NIENHUIS PH. 1995. Free and bound fatty acids and hydroxyl fatty acids in the living and decomposing eelgrass Zostera marina L. Org Geochem 23: 721-728.

DUTRA SJ. 1998. A bacia hidrográfica do Córrego Grande, Ilha de Santa Catarina, Brasil. In: Soriano-Sierra EJ and Ledo BS (Eds), Ecologia e Gerenciamento do Manguezal do Itacorubi, Florianópolis: NEMAR, CCB, UFSC, p. 31-35.

Emeis KC, Struck U, LeIPE T, Pollehme F, KunZendorF H AND Christiansen C. 2000. Changes in the C, N, P burial rates in some Baltic Sea sediments over the last 150 years - relevance to $P$ regeneration rates and the phosphorus cycle. Mar Geol 167: 43-59. 
FARIAS CO, HAMACHER C, WAGENER ALR AND SCOFIELD AL. 2008. Origin and degradation of hydrocarbons in mangrove sediments (Rio de Janeiro, Brazil) contaminated by an oil spill. Org Geochem 39: 289-307.

FERNANDES MB, SicRe MA, CARDOSO JN AND MACEDO SJ. 1999. Sedimentary 4-desmethyl sterols and $n$-alkanols in an eutrophic urban estuary, Capibaribe River, Brazil. Sci Total Environ 231: 1-16.

Garcette-LePeCQ A, LARgeau C, Bouloubassi I, Derenne S, Saliot A, Lorre A And Point V. 2004. Lipids and their modes of occurrence in two surface sediments form Danube delta and northwestern Black Sea: implications for sources and early diagenetic alteration I. Carboxylic acids. Org Geochem 35: 959-980.

Goossens H, De Leeuw JW, Rijpstra WIC, MeyburG GJ AND SCHENCK PA. 1989a. Lipids and their mode of occurrence in a bacteria and sediments - IA methodological study of the lipids composition of Acinetobacter calcoaceticus LMD 79-41. Org Geochem 14: 15-25.

Goossens H, DÜREn RR, De LeEuW JW AND SCHENCK PA. 1989b. Lipids and their mode of occurrence in a bacteria and sediments - II Lipids in the sediment of a stratified, freshwater lake. Org Geochem 14: 27-41.

Grimalt JO, Fernandez P, Bayona JM And Albaiges J. 1990. Assessment of fecal sterols and ketones as indicator of urban sewage inputs to coastal waters. Environ Sci Technol 24: 357-363.

HEFTMANNE. 1971. Functions of sterols in plants. Lipids 6: 128.

Hernandez ME, Mead R, Peralba MC and Jaffé R. 2001. Origin and transport of $n$-alkane-2-ones in a subtropical estuary: potential biomarkers for seagrassderived organic matter. Org Geochem 32: 21-32.

JAFFé R, Rushdi AI, Medeiros PM AND SimoneIt BRT. 2006. Natural product biomarkers as indicators of sources and transport of sedimentary organic matter in a subtropical river. Chemosphere 64: 1870-1884.

KEINÄNEN MM, KORHONEN LK, MARTIKAINEN PJ, VARTiainen T, Miettinen IT, Lehtola MJ, NenOnEN K, Pajunen H and Kontro MH. 2003. Gas chromatographic - mass spectrometric detection of 2- and 3-hydroxy fatty acids as methyl esters from soil, sediment and biofilm. J Chromatog B 783: 443-451.

Killops S AND Killops V. 2005. Introduction to Organic Geochemistry. Second Edition. Blackwell Publishing, UK.

Koch BP, HARDER J, LARA RJ AND KATTNER G. 2005. The effect of selective microbial degradation on the composition of mangrove derived pentacyclic triterpenols in surface sediments. Org Geochem 36: 273-285.

KOCH BP, RULLKÖTTER J AND LARA RJ. 2003. Evaluation of triterpenols and sterols as organic matter biomarkers in a mangrove ecosystem in northern Brazil. Wetl Ecol Manag 11: 257-263.

Koch BP, Souza Filho PWM, Behling H, Cohen MCL, Kattner G, Rullkötter J, SchOlZ-BÖtTCher B AND LARA RJ. 2011. Triterpenols in mangrove sediments as a proxy for organic matter derived from the red mangrove (Rhizophora mangle). Org Geochem 42: 62-73.
LACERDA LD. 1998. Mangrove Ecosystems Occasional Papers No. 2. Vannucci M (Ed), ISME: Okinawa.

LACERDA LD, ITtEKKOT V AND PATCHINEELAM SR. 1995. Biogeochemistry of mangrove soil organic matter: a comparison between Rhizophora and Avicennia soils in south-eastern Brazil. Estuar Coast Shelf Sci 40: 713-720.

LAGO PF. 1997. Ilha de Santa Catarina: urbanização e manejo. Atas do Colóquio Franco-Brasileiro. In: Gestión de la zone littorale de I'lle de Santa Catarina (Brésil).

Lallier-Vergès E, Perrussel B, Disnar JR AND BAltzer F. 1998. Relationships between environmental conditions and the diagenetic evolution of organic matter derived from higher plants in a modern mangrove swamp system (Guadeloupe, French West Indies). Org Geochem 29: 1663-1686.

Madureira las, Van Kreveld SAV, Eglinton G, Conte MH, Ganssen G, Hinte JE And OtTens J. 1997. Late Quaternary High-Resolution biomarker and other sedimentary paleoclimate proxies in a Northeast Atlantic core. Paleoceanography 12: 255-269.

Mater L, Alexandre MR, HANSEl F AND Madureira LAS. 2004. Assessment of lipid compounds and phophorus in mangrove sediments of Santa Catarina Island, Brazil. J Braz Chem Soc 15: 725-734.

Nichols PD AND LEEMING R. 1991. Tracing sewage in the marine environment. Chem Ausralia, July, p. 274-276.

PempKowiak J, Tylmann W, Staniszewski A AND GOLEBIEWSKI R. 2006. Lignin depolymerization products as biomarkers of the organic matter sedimentary record in ${ }^{210} \mathrm{~Pb}$ - ${ }^{137}$ Cs-dated lake sediments. Org Geochem 37: 1452-1464.

Rezende CE, Pfeiffer WC, Martinelli LA, Tsamakis E, HedGeSJI AND KeIL RG. 2010. Lignin phenols used to infer organic matter sources to Sepetiba Bay RJ, Brazil. Estuar Coast Shelf Sci 87: 479-486.

Rieley G, Collier RJ, Jones DM AND Eglinton G. 1991. The biogeochemistry of Ellesmere Lake, U.K.-I: source correlation of leaf wax inputs to the sedimentary lipid record. Org Geochem 17: 901-912.

Ruiz-Fernandéz AC, Hillaire-marcel C, Ghaleb B, SOTO-JIMÉNEZ M AND PAEZ-OSUNA F. 2002. Recent sedimentary history of anthropogenic impacts on the Culiacan River Estuary, northwestern Mexico: geochemical evidence from organic matter and nutrients. Environ Pollut 118: 365-377.

SHEPARD JP. 1954. Nomenclature based on sand-silt-clay ratios. J Sediment Petrol, p. 151-158.

SORIANO-SIERRA EJ AND LEDO BS. 1998. Ecologia e Gerenciamento do Manguezal do Itacorubi. Florianópolis: Série Fepema, Santa Catarina, 408 p.

Suguio K. 1973. Introdução à sedimentologia. Universidade de São Paulo Press, São Paulo, 150 p.

TAKAHASHI T, BROECKER WS AND LANGER S. 1985. Redfield ratio based on chemical-data from isopycnal surfaces. J Geophys Res-Oceans 90: 6907-6924.

VENKATESAN MI AND KAPLAN IR. 1982. Distribution and transport of hydrocarbons in surface sediments of the Alaskan outer continental shelf. Geochim Cosmochim Acta 46: 2135-2149. 
Versteegh GJM, Bosch H-J AND De LeEUW JW. 1997. Potential paleoenvironmental information of $\mathrm{C}_{24}$ to $\mathrm{C}_{36}$ mid-chain diols, keto-ols and mid-chain hydroxyl fatty acids; a critical review. Org Geochem 27: 1-13.

Vogts A, MOOSSEN H, ROMMERSKIRCHEN F AND RULLKÖTTER J. 2009. Distribution pattern and stable isotope composition of alkanes and alkan-1-ols from plant waxes of African rain forest and savanna $\mathrm{C} 3$ species. Org Geochem 40: 1037-1054.

VOLKMAN JK. 1986. A review of sterol markers for marine and terrigenous organic matter. Org Geochem 9: 83-99.
VOLKMAN JK, EGLINTON G AND CORNER EDS. 1980. Sterols and fatty acids of the marine diatom biddulphia sinensis. Phytochemistry 19: 1809-1813.

VOLKMAN JK, REVILL AT, BONHAM PI AND CLEMENTSON LA. 2007. Sources of organic matter in sediments from the Ord River in tropical northern Australia. Org Geochem 38: 1039-1060.

Xu S, Gao X, LiU M and Chen Z. 2001. China's Yangtze estuary: II. Phosphorus and polycyclic aromatic hydrocarbons in tidal flat sediments. Geomorphology 41: 207-217. 